\title{
INFLUENCE OF THE USE OF TECHNOLOGY THROUGH PROBLEM BASED LEARNING AND INKUIRI MODELS ARE LEADING TO SCIENTIFIC COMMUNICATION STUDENTS CLASS VII
}

\author{
Agung Setyawan ${ }^{1} \mathbb{D}$, Nurfina Aznam $^{1} \mathbb{D}$, Paidi $^{1} \mathbb{D}$, Tyasmiarni Citrawati ${ }^{1}$ \\ ${ }^{1}$ Universitas Negeri Yogyakarta (Indonesia) \\ ${ }^{2}$ Universitas Trunojoyo Madura (Indonesia) \\ agung.setyawan2016@student.uny.ac.id,nurfina_aznam@uny.ac.id,paidi@uny.ac.id, \\ tyasmiarni.citrawati@trunojoyo.ac.id
}

Received March 2020

Accepted May 2020

\section{Abstract}

Problem Based Learning (PBL) and guided inquiry learning model develops intellectual ability as part of mental process. The purpose of this research is to know the difference of scientific communication ability between students who learn to use PBL model and guided inquiry, and to know whether there is influence the use of technology through PBL model and guided inquiry model to student scientific communication. The experimental research was conducted in 2 schools (Junior High School \& Madrasah Tsanawiyah) in Grobogan District. Examples consisted of 10 classes with 6 PBL model learning models, 4 guided inquiry model and 1 control class. The sample size is 352 students. Instruments using student worksheets and student research reports. The analysis used a one way variance with a significance level of $5 \%$ supported by students' skill and classical completeness. The results show the PBL model by giving the video at the beginning of learning gives the biggest influence with the average 83,6. The conclusion of this research is the better model of PBL in terms of individual capability, guided inquiry model better in terms of classical mastery. Improving scientific communication skills more effectively using PBL by providing video at the beginning of learning, followed by guided inquiry model with scientific reasoning. scientific communication skills more effectively using PBL with early video-giving activities and guided inquiry models with scientific reasoning.

Keywords - Guided inquiry, Scientific communication, Problem based learning.

\section{To cite this article:}

Setyawan, A., Aznam, N., Paidi, P., \& Citrawati, T. (2020). Influence of the use of technology through problem based learning and Inkuiri models are leading to scientific communication students class VII. Journal of Technology and Science Education, 10(2), 190-198. https://doi.org/10.3926/jotse.962

\section{Introduction}

Learning is a process of interaction of learners with educators and learning resources that occur in the learning environment. The main purpose of the learning process is to achieve the learning objectives supported by various components of learning. Students and teachers are a major component of the learning process. The learning process requires a good reciprocal relationship between teachers and students, so the purpose of learning can be done well. 
The learning process that emphasizes the skills of the science process will build students' self-understanding from the beginning to the end of learning. The learning process of natural Sciences emphasizes the provision of direct experience to develop the competence to understand the material appropriately. The learning model is applied with attention to student involvement in knowledge building when applying the lesson. The use of models in the application of learning also equips students with scientific literacy through experiments while in the learning process.

Initial studies in three junior high schools with the same school accreditation, in Grobogan district concluded that the application of science learning model in the teaching and learning process has not fully imparted the skills of the science process. Commonly applied learning patterns are lectures, discussions and group work. Students feel bored with the learning pattern. They want teaching and learning activities of science with observation and research activities that utilize the school environment. Students are not yet accustomed to communicating scientifically. When the learning process of natural Sciences is seen from the result of the assessment of group work report, the report made still does not meet the component of group work report. This is because students are not yet accustomed to scientifically communicating the work of groups of students.

The learning process is not only to learn from the guidebook given to the students, but the planting and application of the concept of natural Sciences emphasizes the application of everyday life in the environment around the students. The form of assignment (whether searching on the internet, clipping or other supporting literacy sources) is expected to make students motivated in learning. However, when given the assignment of both clipping and student papers are still experiencing difficulties in learning the concept of science.

Learning model is an important element to run student learning activity in school. Implementation of a good learning model on students will facilitate teachers in teaching, and make the learning process good and interesting for students. Through the learning model, teachers can assist students in finding information, skills, ways of thinking, expressing ideas, interacting, taking responsibility and training students' courage Chang, Wang, Ko, Yu, Lin, Tsai, (2017). The literature review used comes from pre-existing research and can be used as the theoretical basis for the research conducted. Here's the title and relevant research results.

Based on the guided inquiry research that has been done by Arslan (2014) that the implementation of the model and the approach that gives students feel comfortable and comfortable to the science learning so that the value obtained by the students beyond the minimum mastery criteria (KKM). Ruiz-Gallardo, Castaño, Gómez-Alday, Valdés (2011) shows that the guided inquiry learning model has an impact on improving conceptual understanding and developing students' creative thinking skills.

Based on preliminary data in the field, students are still unfamiliar in communicating scientifically. Researchers try to raise the problems experienced by students in the form of obstacles in scientific communication written secera in the form of results of observations and lab reports. In this study, the researcher chose the problem based learning model (PBL), and guided inquiry model. From the background of the above problems, further research is needed on the analysis of the difference of scientific communication skills of grade VII students on natural Sciences material based on PBL model and guided inquiry. The expected result of this research is to know the influence of PBL model and guided inquiry to the students' scientific communication ability on the science material of class VII.

The PBL model is a learning model with a learning approach to authentic problems so students can build their own knowledge, grow on higher skills. The PBL model includes asking questions or problems, focusing on interdisciplinary linkages, authentic inquiry, cooperation for critical thinking and problem solving. The inquiry model emphasizes maximum student activity to search and discover. It means that the inquiry model puts the students as subject of learning. In the learning process, students not only act as recipients of the lessons through verbal teacher explanations, but they play a role in finding the essence of the subject matter themselves. In addition, all activities 
undertaken by students are directed to find and find their own answers from something in question, so it is expected to foster self-confidence. Guided inquiry creates the effectiveness and efficiency of time in teaching because of student-centered learning and the role of the teacher as a facilitator and student guide / mentor.

Both PBL and inquiry learning have direct implications such as the progress of learning attitudes, independence, scientific thinking ability, discussion ability, and student cooperation. In studying science the students are not only required to master the thinking skills but also the students are also expected to communicate the results of the product in the form of works / reports both written and oral. Due to the close connection between the ability to think by communicating scientifically. Agreeing with Santrock in Sarwi, Khanafiyah and Rusilowati, (2013) thinks reasoning and arguing can be reinforced in scientific communication skills.

The purpose of this research is to calculate the difference of scientific communication ability of students learning using PBL model and guided inquiry, to calculate the influence of PBL model on students' scientific communication, and to calculate the influence of guided inquiry model to students' scientific communication.

\section{Methodology}

This research is using experimental method. The population in this study are 16 classes in 2 Junior High Schools in Purwodadi and Madrasah Tsanawiyah in Grobogan District. Each class has 32 students. This population selection refers to the same school accreditation and is located in Grobogan District. The data collection technique is done by purposive sampling by looking at the characteristics of each class that have been consulted first with classroom teacher. In each school, five classes were selected to be used as experiments divided according to 3 classes using the PBL model (PBL with early discourse of activity, PBL model with early demonstration activity, PBL model with video giving at the beginning of activity) and 2 classes using Scientific reasoning and without Scientific reasoning. The researcher took 1 control class using the usual practicum model without PBL and Guided Inquiry (using only lectures and practices with the teacher).

The instruments of this study were in the form of student worksheets (LKS), the format of the student research assessment report format, the scientific communication assessment sheet, the student response questionnaire and the student's cognitive value. Data analysis techniques using elements of normality test, homogeneity, and hypothesis testing with ANOVA test. The use of worksheets to help maximize the learning model that is applied. Reports on research results are used to assess scientific communication skills based on prepared assessment sheets. There are nine criteria that researchers use in assessing students' scientific communication: 1) the ability to answer the need for observation. 2) Considerations in discussions raised by students who are submitted in scientific research. 3) Submission of observation variables. 4) Submission of data acquisition procedures. 5) delivery in processing and analyzing data. 6) Presentation of data. 7) Submission of appropriate media to prepare data processing results. 8) Submission of written data. 9) Use of appropriate language, symbols, and terminology for the field of Natural Sciences.

\section{Result}

Data includes anova test results and completeness test results as well as classical. For anova calculations, the researcher uses Microsoft's excel 2010 help shown in Table 1, Table 2 and Table 3. 


\begin{tabular}{|c|c|c|c|c|}
\hline \multicolumn{5}{|c|}{ Summary } \\
\hline Groups & Count & Sum & Average & Variance \\
\hline PBL with early discourse of activity & 64 & 5159.5 & 80.6 & 82.1 \\
\hline PBL model with early demonstration activity & 64 & 5240.1 & 81.9 & 74 \\
\hline PBL model with video giving at the beginning of activity & 64 & 5351.3 & 83.6 & 70.4 \\
\hline Guided inquiry model with scientific reasoning & 64 & 5195.8 & 81.2 & 61.1 \\
\hline Guided inquiry model without scientific reasoning & 64 & 4920.6 & 76.9 & 56.7 \\
\hline
\end{tabular}

\begin{tabular}{|l|r|r|r|r|r|r|}
\hline ANOVA \\
\hline Source of Variation & \multicolumn{1}{|c|}{ ss } & df & \multicolumn{1}{|c|}{ ms } & f & P-value & f crit \\
\hline Between Groups & 1573.8 & 4 & 393.4 & 5.7 & 0.000189 & 2.4 \\
\hline Within Groups & 21694.2 & 315 & & & & \\
\hline Total & 23267.9 & 319 & & & & \\
\hline
\end{tabular}

Table 1. Anova test results

From the table results it can be seen that the value using the $95 \%$ confidence level, alfa $=5 \%$, df 1 (number of variables-1) $=4$, and df 2 (n-5) or 319-4 = 315, the results obtained for Fcount $=5.7$ and Fcrit $=2.4$. Fcount $>$ from Fcrit at 5\% significance level, so Ho is rejected and H1 accepted. So it can be concluded that there are differences in scientific communication skills of learners using PBL model and guided inquiry model. The average value of students' scientific communication to use PBL model with early discourse activity 80.6, PBL with preliminary demonstration activity 81,9, PBL with video early activity 83.6, guided inquiry with scientific reasoning 81.2 , guided inquiry conducted without scientific reasoning 76.9.

\begin{tabular}{|l|r|r|r|r|r|r|}
\hline \multicolumn{7}{|c|}{ Complete ability test using t test technique } \\
\hline & \multicolumn{1}{|c|}{ Junior Hihg School } & \multicolumn{3}{|c|}{ Madrasah Tsanawiyah } \\
\cline { 2 - 6 } & \multicolumn{1}{|c|}{$\boldsymbol{X}$} & \multicolumn{1}{c|}{$\boldsymbol{s}$} & \multicolumn{1}{c|}{$\boldsymbol{T}$} & \multicolumn{1}{c|}{$\boldsymbol{s}$} & \multicolumn{1}{c|}{$\boldsymbol{s}$} \\
\hline PBL with early discourse of activity & 81.3 & 10.2 & 3.4 & 79.9 & 7.9 & 3.5 \\
\hline PBL model with early demonstration activity & 83.1 & 9.7 & 4.7 & 80.6 & 7.3 & 4.3 \\
\hline PBL model with video giving at the beginning of activity & 84.4 & 8.4 & 6.3 & 82.8 & 8.4 & 5.2 \\
\hline Guided inquiry model with scientific reasoning & 82.4 & 7.6 & 5.4 & 77.5 & 6.7 & 2.1 \\
\hline Guided inquiry model without scientific reasoning & 77.9 & 8.4 & 1.9 & 75.8 & 6.2 & 1.8 \\
\hline Control class & 76.9 & 6.3 & 1.7 & & & \\
\hline
\end{tabular}

Table 2. Differences test the ability of each model.

The result of ability test of each model at Junior High School in Purwodadi and Madrasah Tsanawiyah showed that the average of scientific communication execution of PBL model with initial activity of discourse is 81.3 with $\mathrm{t}$ count 3.4 and 79.9 with $\mathrm{t}$ count 4.5 , PBL with activity of beginning of demonstration 81.1 with t hitung 4.8 and 80.6 with $\mathrm{t}$ count 4.3. PBL with activity initial video 84.4 with $\mathrm{t}$ count 6.3 and 82.8 with t count 5.2, guided inquiry with scientific reasoning 82.4 with t count 5.4 and 77.5 with t count 2.1, guided inquiry without scientific reasoning 77.9 with t count 1.9 and 75.8 with t count 1.8, for class control class with 76.9 and t count 1.7 .

The results of classical exhaustiveness test of each model at Junior High School in Purwodadi and Madrasah Tsanawiyah with each class of 32 students showed that the percentage of scientific communication execution PBL model with the initial activity of discourse is $78.1 \%$ with $z$ arithmetic -8.5 and $75 \%$ with $z$ arithmetic -8.5 , PBL with $84.4 \%$ initial demonstration activity with $z$ count -8.5 and $81.3 \%$ with $z$ arithmetic -8.5 , PBL with $87.5 \%$ initial video activity with $z$ arithmetic -8.5 and $84.4 \%$ with $z$ arithmetic -8.5 , guided inquiry with scientific reasoning $93.8 \%$ with $z$ count -8.5 and $87.5 \%$ with $z$ count -8.5 , inquiry guided without scientific reasoning $78.1 \%$ with $\mathrm{z}$ arithmetic -8.5 and $81.3 \%$ with $\mathrm{t}$ arithmetic -8.5 . 


\begin{tabular}{|c|c|c|c|c|c|}
\hline \multicolumn{6}{|c|}{ Classic completeness at Junior High School in Purwodadi Grobogan District using z arithmetic } \\
\hline & $\begin{array}{l}\text { PBL with early } \\
\text { discourse of } \\
\text { activity }\end{array}$ & $\begin{array}{c}\text { PBL model with } \\
\text { early } \\
\text { demonstration } \\
\text { activity }\end{array}$ & $\begin{array}{l}\text { PBL model with } \\
\text { video giving at } \\
\text { the beginning } \\
\text { of activity }\end{array}$ & $\begin{array}{l}\text { Guided inquiry } \\
\text { model with } \\
\text { scientific } \\
\text { reasoning }\end{array}$ & $\begin{array}{l}\text { Guided inquiry } \\
\text { model without } \\
\text { scientific } \\
\text { reasoning }\end{array}$ \\
\hline$x$ & 25 & 27 & 28 & 30 & 25 \\
\hline$n$ & 32 & 32 & 32 & 32 & 32 \\
\hline z & -8.5 & -8.5 & -8.5 & -8.5 & -8.5 \\
\hline percentage & $78.1 \%$ & $84.4 \%$ & $87.5 \%$ & $93.8 \%$ & $78.1 \%$ \\
\hline \multicolumn{6}{|c|}{ Classic mastery on Madrasah Tsanawiyah Grobogan District } \\
\hline$x$ & 24 & 26 & 27 & 28 & 26 \\
\hline$n$ & 32 & 32 & 32 & 32 & 32 \\
\hline$z$ & -8.5 & -8.5 & -8.5 & -8.5 & -8.5 \\
\hline percentage & $75 \%$ & $81.3 \%$ & $84.4 \%$ & $87.5 \%$ & $81.3 \%$ \\
\hline
\end{tabular}

Table 3. Differences classical exhaustiveness test on each model

The results showed that there are differences in scientific communication skills between students learning using PBL model and guided inquiry. It is reviewed from the anova test, mastery of students' classic ability and completeness. Anova test results show that Fcount $=6.1$ and Fcrit $=2.4$. Fcount $>$ of Fcrit at a significance level of $5 \%$. The average value of scientific communication of students to use PBL model with early activity of discourse 80.6, PBL with preliminary demonstration activity 81.9, PBL with video early activity 83.6, guided inquiry with scientific reasoning 81.2 , guided inquiry with scientific reasoning 76.9, control class class 76.9. Learning with the use of PBL model is superior to guided inquiry. The most dominant PBL learning is the PBL learning by giving the video at the beginning of the lesson. This agrees with what Saharsa, Qaddafi and Baharuddin (2018) say that learning PBL with video media can improve students' critical thinking skills. Students who are able to think critically show that students look more active and enthusiastic, resulting in cooperation and willing to interact, help each other and share opinions, listen to opinions of friends in completing the task. Of the 5 groups, $80 \%$ more students can complete their competencies well and in accordance with the time specified.

The result of calculation of scientific communication skill mastery at Junior High School in Purwodadi Grobogan Regency using PBL model obtained 83\%, while completeness of scientific communication ability using guided inquiry model is $80.1 \%$. Calculation results on Madrasah Tsanawiyah District Grobogan completeness scientific communication ability using PBL model obtained $81.1 \%$, while the completeness of scientific communication skills using guided inquiry model obtained $76.7 \%$. In each school there are differences in the completeness of scientific communication skills where the application of PBL model is superior to the application of guided inquiry model. Application of PBL model at Junior High School in Purwodadi Grobogan Regency is better 2.8\% while application of PBL model on Madrasah Tsanawiyah Grobogan Regency is better 4.5\%. Overall the application of PBL model model is better than the application of guided inquiry model in which the completeness of scientific communication model aspect of PBL model in research is $82 \%$ and the completeness of scientific communication model aspect of Inkuiri model is guided in the research of $78.4 \%$ or it can be said the application of PBL model is better 3.6\% judging from the mastery of students' scientific communication skills. Completeness of the ability to apply PBL learning model shows the highest score especially on PBL learning with early video activity because PBL is a good technique to increase student activity, comprehend the content of the lesson and challenge student ability and give satisfaction to find new knowledge for student. In addition, the students' cognitive learning outcomes show the highest score among other model uses aimed at the student's daily repeat value after the application of the PBL model by giving the video at the beginning of the learning with an average student score of 8.63. In line with what Liu, Du, Zhang, Zhou, (2019) that PBL positively influence the significant implementation of problem based learning on the independence of science learning. By giving early activities of the video the students can be motivated and know what will be done later to solve the problems given by the teacher. 
The result of calculation at Junior High School in Purwodadi Grobogan District, the classical completeness of scientific communication using PBL model is $83.3 \%$, while the classical completeness of scientific communication using guided inquiry model is $85.9 \%$. Calculation results on Madrasah Tsanawiyah District Grobogan classical completeness of scientific communication using PBL model obtained $80.2 \%$ while the classical completeness of scientific communication aspects using guided inquiry model obtained $84.4 \%$. In each school there are differences in the classical completeness of scientific communication aspects where the application of guided inquiry model is better than the application of PBL model. The implementation of guided inquiry model in Junior Hihg School is better $2.6 \%$ while the implementation of guided inquiry model in Madrasah Tsanawiyah Grobogan District is better 4.2\%. Overall the implementation of guided inquiry model model is superior to the application of PBL model where the classical completeness of the scientific communication model of PBL model in the research is $81.8 \%$ and the classical completeness of scientific communication model of Inkuiri model is guided in the research of $85.2 \%$ or it can be said the application of guided inquiry model is better $3.4 \%$ in terms of classical completeness of students' scientific communication aspects.

The results showed that there is an influence between the PBL model on students' scientific communication in terms of the mastery of the ability by comparing the control class and experimental class. The result of the calculation on the completeness of scientific communication method using PBL model by giving the discourse at the beginning of learning in Junior Hihg School obtained 81.3\%, completeness of scientific communication method using PBL model by giving demonstration at the beginning of learning at Junior High School in Purwodadi Grobogan Regency obtained 83.1\%, completeness of scientific communication method using PBL model by giving video at the beginning of learning at Junior High School in Purwodadi Grobogan Regency obtained 84.4\%, completeness of scientific communication method using PBL model by giving discourse at the beginning of learning on Madrasah Tsanawiyah Grobogan District obtained 79.9\%, completeness of scientific communication skills using PBL model by giving demonstration at the beginning of MTs learning. Yarobi Grobogan District obtained 80.6\%, mastery of the ability of scientific communication aspects using PBL model by providing video at the beginning of learning on Madrasah Tsanawiyah Kabupaten Grobogan obtained 82.8\%.

From the results of data analysis in each class showed that learning using the PBL model gives influence to students' scientific communication both PBL model is given the early activities of discourse, demonstration and video. With the PBL learning model can achieve the learning objectives and the average student has exceeded the established KKM that is 75. Giving initial activity in the form of discourse is the lowest result in the analysis of researchers. It is possible students have not really know what the students will do later because the delivery is still an oral discourse and question and answer between teachers with students before doing observation activities. Agreeing with Benli and Sarikaya (2012) states that the essence of PBL presents a variety of authentic and meaningful problem situations to students, which can serve as a springboard for investigation and investigation. PBL is designed to help students develop thinking skills and problem-solving skills, learn the roles of adults and become independent learners. In line with Nicholls (2014), Morgado and Leite (2013) stated that the purpose of PBL is to help students develop thinking skills and problem-solving skills, learning the role of an authentic adult and becoming an independent learner.

The result of the research shows that there is influence between guided inquiry model to students' scientific communication in terms of mastery of ability by comparing control class class and experiment. The inquiry model is guided by scientific reasoning which gives higher influence compared to guided inquiry model with scientific reasoning in terms of mastery of the ability and classical completeness.

The result of the calculation on the completeness test of scientific communication method using guided inquiry model with scientific reasoning at Junior High School in Purwodadi Grobogan Regency 82.4\%, completeness test of scientific communication aspect using guided inquiry model with no scientific reasoning at Junior High School in Purwodadi Grobogan Regency 77.9\% completeness test of scientific communication aspect using guided inquiry model with scientific reasoning on Madrasah Tsanawiyah Grobogan District $77.5 \%$, completeness test of scientific communication aspects using guided inquiry model with no scientific reasoning on Madrasah Tsanawiyah Regency Grobogan 85.8\%. 
From the results of data analysis shows that the use of model inquiry model guided by scientific reasoning and guided inquiry model without scientific reasoning. Gives effect to the mastery of ability where the average student has exceeded the applied KKM that is 75 . The use of guided inquiry model with scientific reasoning is considered more rather than the use of guided inquiry models with no scientific reasoning with higher completeness results in the two different sample schools. This also agrees with the research of Khanafiyah \& Rusilowati (2010) that inquiry gives students the freedom to develop creativity, learners will be more creative in developing their experimental objectives, and improve the ability to understand the material. Agree with the research McNew-Birren and Kieboom (2017), Kant, Scheiter and Oschatz (2017) that the application of inquiry learning triggers the increase of the students' process skills in practicum. In line with Roller and Zori (2017), Howell and Saye (2018) the inquiry model involves a process of exploring nature that leads to the process of asking questions, making discoveries, testing discoveries and solving problems to seek new understanding, so as to encourage students' scientific reasoning which is one of the goals of education. Guided inquiry learning has an impact on students' scientific communication. The existence of findings beyond the previous estimate of the researchers, among others, counting on the class control class showed higher results compared to guided inquiry without scientific reasoning. The researcher assumed that the selection of control class classes was taken last which enabled the influence of the teacher as a model that brought the atmosphere of PBL activity and guided inquiry into the control class class. In addition, the possibility of students in the classroom control class has obtained information from the experimental class before doing research on control class class. Jiang, Clarke-Midura, Keller, Baker, Paquette and Ocumpaugh (2018) in his research shows that inquiry learning model is effective and efficient to implement science learning. The inquiry model involves a process that leads to asking questions, making discoveries, testing discoveries and solving problems to seek new understanding, so as to encourage students' scientific reasoning which is one of the goals of education.

\section{Conclusions}

The findings obtained from this study there are differences in scientific communication skills of students who learn to use the PBL model and guided inquiry that uses technology. There is influence of use of technology in the problem based learning model (PBL) to student scientific communication. The PBL model by providing video at the beginning of learning has a higher impact than the PBL model by providing early discourse to learning as well as PBL by giving a demonstration at the beginning of the lesson. In addition PBL video also gives the most significant impact on students' cognitive learning outcomes. There is influence of guided inquiry model to student's scientific communication. The inquiry model is guided by scientific reasoning giving higher influence than guided inquiry model without scientific reasoning.

\section{Declaration of Conflicting Interests}

The author declared no potential conflicts of interest with respect to the research, authorship, and/or publication of this article.

\section{Funding}

The paper was sponsored by Lembaga Pengelola Dana Pendidikan (LPDP). 


\section{References}

Arslan, A. (2014).Transition between Open and Guided Inquiry Instruction. Procedia - Social and Behavioral Sciences, 141, 407-412. https://doi.org/10.1016/j.sbspro.2014.05.071

Benli, E., \& Sarikaya, M. (2012). The Investigation of the Effect of Problem Based Learning to the Academic Achievement and the Permanence of Knowledge of Prospective Science Teacher: The Problem of the Boiler Stone. Procedia - Social and Behavioral Sciences, 46, 4317-4322. https://doi.org/10.1016/j.sbspro.2012.06.247

Chang, H., Wang, N., Ko, W., Yu, Y., Lin, L., \& Tsai, L. (2017). The effectiveness of clinical problem-based learning model of medico-jurisprudence education on general law knowledge for Obstetrics/Gynecological interns. Taiwanese Journal of Obstetrics and Gynecology, 56(3), 325-330. https://doi.org/10.1016/j.tjog.2017.04.011

Howell, J.B., \& Saye, J.W. (2018). Integrating theory and practice: Factors shaping elementary teachers' interpretation of an inquiry model for teaching social studies. The Journal of Social Studies Research, 42(2), 201-214. https://doi.org/10.1016/j.jssr.2017.04.003

Jiang, Y., Clarke-Midura, J., Keller, B., Baker, R.S., Paquette, L., \& Ocumpaugh, J. (2018). Note-taking and science inquiry in an open-ended learning environment. Contemporary Educational Psychology, 55, 12-29. https://doi.org/10.1016/j.cedpsych.2018.08.004

Kant, J.M., Scheiter, K., \& Oschatz K. (2017). How to sequence video modeling examples and inquiry tasks to foster scientific reasoning. Learning and Instruction, 52, 46-58.

https://doi.org/10.1016/j.learninstruc.2017.04.005

Khanafiyah, S., \& Rusilowati, A. (2010). Penerapan Pendekatan Modified Free Inquiry Sebagai Upaya Meningkatkan Kreativitas Mahasiswa Calon Guru dalam Mengembangkan Jenis Eksperimen dan Pemahaman Terhadap Materi Fisika. Jurnal Penelitian Pendidikan, 27(2), 179-185.

https://doi.org/10.15294/ipp.v27i2.179

Liu, L., Du, X., Zhang, Z., \& Zhou, J. (2019). Effect of problem-based learning in pharmacology education: A meta-analysis. Studies in Educational Evaluation, 60, 43-58.

https://doi.org/10.1016/j.stueduc.2018.11.004

McNew-Birren, J., \& Kieboom, L.A.v.d. (2017). Exploring the development of core teaching practices in the context of inquiry-based science instruction: An interpretive case study. Teaching and Teacher Education, 66, 74-87. https://doi.org/10.1016/j.tate.2017.04.001

Morgado, S., \& Leite, L. (2013). Science and Geography Teachers' Conceptions Regarding Problem-based Learning Related Concepts. Procedia - Social and Behavioral Sciences, 106, 2343-2347. https://doi.org/10.1016/j.sbspro.2013.12.268

Nicholls, J. (2014). Teaching and evaluation of basic pathological sciences in a generation of problem based learning. Pathology, 46(2), S32. https://doi.org/10.1097/01.PAT.0000454193.12666.21

Roller, M.C., \& Zori, S. (2017). The impact of instituting Process-Oriented Guided-Inquiry Learning (POGIL) in a fundamental nursing course. Nurse Education Today, 50, 72-76.

https://doi.org/10.1016/j.nedt.2016.12.003

Ruiz-Gallardo, J., Castaño, S., Gómez-Alday, J.J., \& Valdés, A. (2011). Assessing student workload in Problem Based Learning: Relationships among teaching method, student workload and achievement. A case study in Natural Sciences. Teaching and Teacher Education, 27(3), 619-627. https://doi.org/10.1016/j.tate.2010.11.001

Saharsa, U., Qaddafi, M., Baharuddin, B. (2018). Efektivitas Penerapan Model Pembelajaran Problem Based Learning Berbantuan Video Based Laboratory Terhadap Peningkatan Pemahaman Konsep Fisika. Jurnal Pendidikan Fisika, 6(2). https://doi.org/10.24252/jpf.v6i2a2 
Sarwi, Khanafiyah, S., Rusilowati, A. (2013). Implementasi Model Eksperimen Gelombang Open-Inquiry Untuk Mengembangkan Keterampilan Komunikasi Ilmiah Mahasiswa Fisika. Jurnal Pendidikan fisika Indonesia, 9(2), 123-131. https://doi.org/10.15294/jpfi.v9i2.3028

Published by OmniaScience (www.omniascience.com)

Journal of Technology and Science Education, 2020 (www.jotse.org)

\section{(ㄷ) (1) $(9$}

Article's contents are provided on an Attribution-Non Commercial 4.0 Creative commons International License.

Readers are allowed to copy, distribute and communicate article's contents, provided the author's and JOTSE

journal's names are included. It must not be used for commercial purposes. To see the complete licence contents, please visit https://creativecommons.org/licenses/by-nc/4.0/. 